\title{
Monoclonal antibodies to Gliocladium roseum, a potential biological control fungus of sap-staining fungi in wood
}

\author{
Colette Breuil, ${ }^{*}$ Brian T. LuCK, ${ }^{2}$ LynNe Rossignol, ${ }^{3}$ Judy Little, ${ }^{2}$ \\ Christophe J. Echeverri, ${ }^{2}$ SRABani BanerJeE ${ }^{2}$ and David L. Brown ${ }^{2}$ \\ ${ }^{1}$ Forest Products Biotechnology, Faculty of Forestry, University of British Columbia, 2357 Main Mall, Vancouver, \\ Canada V6T $1 Z 4$ \\ ${ }^{2}$ Department of Biology, University of Ottawa, Ottawa, Canada K1N $6 N 5$ \\ ${ }^{3}$ Forintek Canada Corp., 800 Montreal Road, Ottawa, Canada KIG $3 G 5$
}

(Received 27 May 1992; revised 20 July 1992; accepted 30 July 1992)

\begin{abstract}
Immunological probes were developed to discriminate between a potential biological control fungus and sapstaining fungi present in wood. This paper describes the production of monoclonal antibodies to isolated cell wall fragments of the biological control fungus Gliocladium roseum. Two monoclonals, designated 6A5 and 3F12, were characterized. Their specificity was assessed by ELISA, by immunogold silver staining light microscopy, by immunogold electron microscopy, and by immunoblotting. Monoclonal 6A5 specifically recognized G. roseum and closely related species and did not react with any of 21 sap-staining fungi tested. Monoclonal $3 F 12$ recognized most of the biological control fungi tested and also showed reactivity with two of the 21 sap-staining fungi. Both monoclonals appeared to recognize carbohydrate epitopes of the cell wall in $G$. roseum. Although the antibodies were produced against the cell wall of fungus grown in liquid culture, they also detected specific fungi in wood and, therefore, can be used for studies of wood colonization by fungi and for investigations of the interactions between different fungi growing on wood.
\end{abstract}

\section{Introduction}

The problem of sap-stain in unseasoned lumber continues to plague the wood products industry, but basic information on the frequency and colonization of the causal organisms is scarce. Seifert et al. (1988) have shown that stain could be reduced or prevented if wood blocks of Jack pine were inoculated with a biological control fungus prior to inoculation with a sap-stain fungus. In that study several fungi, including Gliocladium roseum, were shown to have some potential for controlling the growth of sap-staining fungi in unseasoned lumber. For better assessment of the potential of various biological control fungi, and to analyse their interaction with staining fungi, a serological assay was developed to quantify the fungal colonization of wood (Breuil et al., $1988 a, b)$.

The antiserum used in these earlier studies was produced against the whole mycelium of a staining

* Author for correspondence. Tel. (604) 2223200 ; fax (604) 2223207.

Abbreviation: IGSS, immunogold silver staining. fungus, Ophiostoma piceae, and as a result, varying degrees of cross-reactivity with other staining or biological control fungi occurred. Discrimination between $O$. piceae and the potential biological control fungus G. roseum, however, was improved by pre-absorbing the serum with mycelium of $G$. roseum (Luck et al., 1990). This indicated that the antiserum did contain antibodies recognizing antigens specific to $O$. piceae, the original immunogen, and immunogold electron microscopy showed that these specific antigens were localized in the fungal cell wall (Luck et al., 1990).

As an approach to overcome the problem of antibody cross-reactivity, and to have unlimited amounts of specific antibody available for our assays, we initiated a project to produce monoclonal antibodies to cell wall fragments isolated from $G$. roseum and from $O$. piceae. Monoclonal antibodies with varying degrees of specificity to fungal genus, species and race have been produced by others (e.g. Banowetz et al., 1984; Mitchell, 1986; Dewey et al., 1989a, b). Such monoclonals have been used successfully to detect components of fungal plant pathogens (Benhamou et al., 1985; Ouellette \& Benhamou, 1987) and fungal enzymes in culture and in 
wood (McHale, 1987; Green et al., 1991; Nieves et al., 1991).

This paper describes the production of monoclonal antibodies to isolated cell wall fragments of $G$. roseum and the characterization of two of the monoclonals produced. These antibodies will be of value in analysing wood colonization by $G$. roseum and in assessing the efficacy of this fungus as a biological control agent.

\section{Methods}

Fungal cultures. The different staining fungi (letters designate different isolates of the same species) Ophiostoma piceae $387 \mathrm{E}, \mathrm{H}, \mathrm{I}, \mathrm{J}$, $\mathrm{N}$, Ophiostoma sp. C28, O. piliferum $55 \mathrm{H}, O$. ulmi $437 \mathrm{C}, O$. ainoae 701 A, O. populinum 671 A, Ceratocystis adiposa 251 B, Rhinocladiella atrovirens $135 \mathrm{E}$, Cephaloascus fragrans 307 I, Aureobasidium pullulans $132 \mathrm{Q}$, Phialophora botulispora 707 A, Alternaria alternata $2 \mathrm{G}$, Leptondontidium elatius 268 A, Cladosporium cladosporoides 273 D, Phoma sp. 86-8-3-2-1, Leptographium sp. 2A 2, a black yeast 8-10-1-1-1 and the different biological control fungi Gliocladium roseum $321 \mathrm{~A}$, B, E, I, L, T2, G. aurifilum 675 A, G. catenulentum 786 A, Nectria cinnabarina 405 A, E, D, Hypocrea gelatinosa 418 A, Trichoderma polysporum $260 \mathrm{D}, T$. harzianum $160 \mathrm{O}, \mathrm{P}, T$, viride $161 \mathrm{~A}, \mathrm{I}, \mathrm{Q}, T$. pseudokoningii $228 \mathrm{~B}$, Tympanis hypopodia $162 \mathrm{~B}$, Penicillium thomii 655 A, B, Tympanis sp. 732 A, C54, and Clonostachys compactiuscula 796 A were from the Forintek culture collection. The fungal species were maintained on malt agar slants and grown up in a liquid medium containing $\left(1^{-1}\right) 4.0 \mathrm{~g}$ yeast extract, $4.0 \mathrm{~g}$ D-glucose and $10.0 \mathrm{~g}$ malt extract (Breuil et al., 1988b), for $4 \mathrm{~d}$ on a rotary shaker at $26^{\circ} \mathrm{C}$. The mycelium was harvested and washed in phosphate-buffered saline (PBS; $0.05 \mathrm{M}$-sodium phosphate, $0.8 \mathrm{M}-\mathrm{NaCl}$ ) with $0.002 \%$ merthiolate at $\mathrm{pH} 7 \cdot 4$, and was stored at $-20^{\circ} \mathrm{C}$.

Isolation of cell walls from $G$. roseum and $O$. piceae. Fungi were grown in 10 litre batches. The washed mycelia of $O$. piceae $387 \mathrm{E}(4 \mathrm{~g}$ dry wt) and of $G$. roseum 321 B $(2 \mathrm{~g}$ dry wt) were transferred to a homogenization flask as a $30 \mathrm{ml}$ cell suspension containing $2 \mathrm{ml} 0.4 \mathrm{M}$ phenylmethylsulphonyl fluoride as a protease inhibitor. The cells were disrupted in a Braun homogenizer cooled by a constant stream of $\mathrm{CO}_{2}$. Breakage was determined at intervals by phase contrast light microscopy. Following rupture the cell walls were harvested by centrifugation, and residual cytoplasm was removed by repeated washing in PBS/merthiolate followed by centrifugation. After every second wash, preparations were either gently treated by sonication for $30 \mathrm{~s}$ in short pulses or passed 10 times through a 23 gauge syringe needle. Twenty to forty washes were required to obtain clean cell walls of $O$. piceae or $G$. roseum, respectively. At various stages during the isolation, disrupted cell wall samples were processed for electron microscopy and preparations that were judged to be free of contamination were used as antigen in ELISAs or to immunize Balb/c mice for the production of monoclonal antibodies.

Production of monoclonal antibodies. Female Balb/c mice (age 10 weeks) were immunized with purified cell wall by three intraperitoneal injections at 12-14 d intervals. Pre-immune blood was collected from the tails prior to the first injection. The first injection consisted of $1 \mathrm{mg}$ of isolated cell wall material from $G$. roseum that was suspended in $100 \mu 1$ PBS and emulsified with $100 \mu 1$ Freund's complete adjuvant; the second and third injections consisted of a similar amount of cell wall material in PBS, emulsified with Freund's incomplete adjuvant. Ten days after the third injection, $\mathbf{0 . 2} \mathrm{ml}$ blood samples were collected from the tail vein of each animal, allowed to clot, and serum was separated by centrifugation. Antibody production was assayed by immunofluorescence staining (Chaly et al., 1984) and/or by an ELISA as described below.

Twelve days after the last injection, two mice with the highest specific antibody titres were given an intravenous injection consisting of $200 \mu \mathrm{g}$ of isolated cell walls in $200 \mu \mathrm{l}$ of PBS. Three days later their splenocytes were fused with an $\mathrm{Sp} 2-0 / \mathrm{Ag} 14$ mouse myeloma cell line according to the procedure of Kennett (1984). CPSR-3, a substitute medium, was used for cell culture. HAT-resistant cells appeared macroscopically within 2 weeks. Supernatants were tested for antibody against $G$. roseum by ELISA. The positive cultures were cloned in hybridoma medium containing $0.2 \%$ agar. After $10-14 \mathrm{~d}$ isolated identifiable clones were transferred to 96-well plates, tested for antibody production and expanded. Some cells were used in the production of ascites fluid while other cells were suspended in foetal calf serum or CPSR -3 containing $5 \%(v / v)$ dimethylsulphoxide and stored at $-80^{\circ} \mathrm{C}$.

The induction, production and tapping of ascitic fluid from Balb/c mice was carried out according to Campbell (1984). Monoclonal antibodies were purified from ascites fluid by hydroxylapatite chromatography according to Stanker et al. (1985). Fractions (4 ml) were monitored with a spectrophotometer at $280 \mathrm{~nm}$ and were analysed by ELISA for antibody against $G$. roseum. Positive fractions were pooled and concentrated by dialysis against polyethylene glycol $\left(M_{\mathrm{r}}\right.$ 20000). After dialysis the antibodies were lyophilized, stored at $4{ }^{\circ} \mathrm{C}$ and reconstituted when necessary.

Antibody class and subclass were determined by ELISA using a Zymed mouse isotyping kit following the manufacturer's instructions. The specificity of the monoclonal antibodies was investigated by testing them for reactivity against the cell wall fractions and/or fragmented mycelia of other fungi. For the assays, ELISA plate wells were coated with an equal amount by dry weight of isolated cell walls or with fragmented mycelia. The antigen in $100 \mu \mathrm{l} 0.1 \mathrm{M}$-sodium carbonate buffer, $\mathrm{pH} 9 \cdot 6$, was incubated overnight at $37^{\circ} \mathrm{C}$. The monoclonal antibodies were used at dilutions of between $1: 18$ and $1: 100000$.

ELISA. Routine ELISA using cell walls or fragmented mycelia was performed to measure monoclonal antibody activity according to the procedure of Voller et al. (1979) and as described by Breuil et al. (1988a, $b$ ). For the biotin-streptavidin amplification, the biotinylated secondary antibody was diluted 1:250 and the streptavidin-horseradishperoxidase complex $1: 750$ with $0.5 \%$ casein in PBS, and each was incubated with the test samples for $1 \mathrm{~h}$ at $37^{\circ} \mathrm{C}$.

In some experiments, $G$. roseum cell walls, prepared as above, were treated at room temperature with $0.05 \mathrm{M}$-sodium metaperiodate in 0.01 $\mathrm{M}$-acetate buffer, $\mathrm{pH} \mathrm{4.5}$, for periods of 20 to $240 \mathrm{~min}$ in order to oxidize sugar residues and thereby modify the carbohydrate moieties of glycoproteins (Hearn et al., 1990). The reaction was stopped by addition of sodium bisulphite, after which the samples were diluted with $0.1 \mathrm{M}$-sodium carbonate and coated onto 96-well plates; the binding of the monoclonal antibodies to treated and untreated samples was then determined by ELISA (Breuil et al., 1988a, b). All experiments were repeated and each assay was done at least four times.

SDS-PAGE and Western blotting of cell wall protein extract. Cell wall material was briefly sonicated and centrifuged at 13000 r.p.m. for $5 \mathrm{~min}$. Cell wall protein in the pellet was extracted by brief sonication, followed by boiling for $15 \mathrm{~min}$ in $2 \%$ SDS in PBS. After centrifugation at 13000 r.p.m. for $5 \mathrm{~min}$, the supernatant was recovered, and the pellet resuspended in half the volume of SDS solution to perform a second extraction, identical to the first. Protein was determined in both supernatants separately, by the bicinchoninic acid method, using appropriate controls (Smith et al., 1985). When necessary, samples were concentrated by lyophilization.

$G$. roseum and $O$. piceae cell wall protein extracts $(35 \mu \mathrm{g}$ per well) were separated by SDS-PAGE on a $9 \%$ gel (Laemmli, 1970), using the 
Bio-Rad Mini-Protean II apparatus. Proteins were then transferred onto nitrocellulose by electroblotting overnight at $30 \mathrm{~V} / 90 \mathrm{~mA}$. The nitro-cellulose membranes were then washed in PBS with $0.3 \%$ Tween20 (PBS-T). Proteins were stained in $0.1 \%$ India ink (Pelikan) in PBS$\mathrm{T}$, for $1 \mathrm{~h}$, followed by destaining in PBS-T. The blot was then blocked in $2 \%(\mathrm{w} / \mathrm{v})$ skim milk (Carnation) in PBS for at least $2 \mathrm{~h}$ at $4{ }^{\circ} \mathrm{C}$.

Western blotting was carried out using a Miniblotter apparatus (Immunetics) for primary antibody incubations. Antibodies were diluted, $1: 1500$ for $6 \mathrm{~A} 5$ and $1: 300$ for $3 \mathrm{~F} 12$, in PBS containing $0.1 \%$ skim milk and incubated in adjacent lanes on the same protein samples for $4 \mathrm{~h}$ at room temperature. After a brief PBS wash, blots were placed into $10 \mathrm{~cm}$ disposable plastic petri dishes, and incubated overnight at room temperature, in ${ }^{125}$ I-labelled goat anti-mouse IgM [specific activity $8.97 \mu \mathrm{Ci} \mathrm{mg}^{-1}\left(332 \mathrm{kBq} \mathrm{mg}^{-1}\right) ; 0.5 \mu \mathrm{Ci} \mathrm{ml}^{-1}\left(18.5 \mathrm{kBq} \mathrm{ml}^{-1}\right)$ ] diluted in $10 \mathrm{ml}$ of PBS with $0.1 \%$ skim milk. The blots were finally washed in three changes of PBS-T over $2 \mathrm{~h}$, air-dried, and mounted for autoradiography. This was carried out using Kodak X-OMAT-AR film, exposed for $4 \mathrm{~h}$ at room temperature, using a single Quanta III intensifying screen.

Inoculation of pine wood blocks and immunogold silver staining (IGSS). Unseasoned blocks of Pinus banksiana sapwood were inoculated with a fungal suspension according to Luck et al. (1990). Sections $20 \mu \mathrm{m}$ thick were made with a Spencer sliding microtome after 3-4 weeks of fungal colonization. They were fixed in $0.5 \%$ glutaraldehyde in PHEM buffer

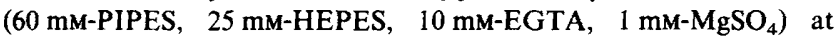
pH 6.9 for $30 \mathrm{~min}$ and processed according to the Janssen (Janssen Biotech, Belgium) procedure for immunogold silver staining. Sections were incubated for $1 \mathrm{~h}$ in monoclonals $6 \mathrm{~A} 5$ or $3 \mathrm{~F} 12$ diluted $1: 500$. The secondary antibody was AuroProbe One goat anti-mouse IgM $(H+L)$. Gold particles were amplified with silver using the Janssen Intense M kit based on the procedure of Holgate et al. (1983). Sections of wood infected with fungi were examined with a Zeiss Axioplan microscope and phase contrast optics. The application of the IGSS method for the detection of fungi in wood has been described previously (Breuil et al., 1990).

Electron microscopy and immunogold labelling. O.piceae and G. roseum cells or isolated cell walls were processed for electron microscopy according to Luck et al. (1990). Isolated cell walls were fixed with glutaraldehyde only and were embedded in LR White medium. Whole cells were fixed with glutaraldehyde followed by osmium tetroxide and were embedded in Spurr's resin. Silver-gold sections of walls and cells were collected on $\mathbf{4 0 0}$ mesh nickel grids coated with parlodion. They were then incubated on a drop of $0.15 \mathrm{M}$-glycine in PBS containing $0.01 \%$ Triton X-100 (PBS-TX) for 30 min to quench residual aldehyde groups, washed with PBS, and incubated on $1 \%(w / v)$ casein in PBS for $20 \mathrm{~min}$ to block nonspecific antibody binding. The sections were subsequently incubated with either (i) PBS-T or (ii) monoclonal antibodies diluted $1: 5000$ with PBS-T. Grids were thoroughly washed with PBS-T and incubated with goat anti-mouse IgM coated $10 \mathrm{~nm}$ colloidal gold diluted $1: 150$ with PBS-T. All incubation steps were done at room temperature. Sections were stained with lead citrate, washed with distilled water and air dried. They were then post-stained with $1 \%(\mathrm{w} / \mathrm{v})$ uranyl acetate in $50 \%(\mathrm{v} / \mathrm{v})$ ethanol, washed with $50 \%$ ethanol and examined with a Philips $201 \mathrm{C}$ electron microscope.

Reagents. Yeast extract, malt extract and agar were purchased from Difco. Phenylmethylsulphonyl fluoride, CPSR-3, oxaloacetate, pyruvate, insulin, HT medium supplement, aminopterin, D-glucose, dimethylsulphoxide, polyethylene glycol, the bicinchoninic acid protein assay kit, Freund's complete and incomplete adjuvant, pristane, goat anti-mouse IgM colloidal gold, $O$-phenylenediamine and $30 \%$ $\mathrm{H}_{2} \mathrm{O}_{2}$ were from Sigma. Microtitre plates (Dynatech Immulon 1) were from Fisher Scientific. Goat anti-mouse IgG and IgM conjugated horseradish peroxidase was from Bio-Rad. AuroProbe One goat anti- mouse Ig $(H+L)$, the biotinylated secondary antibody, the streptavidin-horseradish-peroxidase complex, and the Janssen Intense $\mathbf{M}$ kit were from Amersham. The ${ }^{125}$ I-labelled goat anti-mouse IgM was from Dupont/NEN. The monoclonal isotyping ELISA kit was from Zymed. Dulbecco's MEM, NCTC 109, antibiotic-antimycotic, gentamicin and tissue culture plates were from Gibco/BRL. Nickel grids, glutaraldehyde, osmium tetroxide, sodium cacodylate, LR White and Spurr's resin mixtures were from J. B. EM Services Inc., Pointe-Claire, Québec. Balb/c mice were from Charles River Canada Inc., St Constant, Québec.

\section{Results}

\section{Preparation and characterization of monoclonal antibodies}

At various stages during the isolation procedure, cell wall suspensions were prepared for electron microscopy and were examined for cytoplasmic contamination by electron microscopy (Fig. 1). Preparations that were judged to have a minimum of contamination were used to immunize Balb/c mice for the production of monoclonal antibodies. Two cell fusions were carried out using the $\mathrm{Sp}$ 2-O/Ag 14 myeloma line and about 300 hybrids were screened by immunofluorescence (Chaly et al., 1984) using both $G$. roseum and $O$. piceae cell walls. From this initial screening we isolated and expanded 23 hybridomas which appeared to be producing antibody specific to $G$. roseum. These cell lines were cloned in soft agar, expanded again and rescreened. Sixteen of the hybridomas were stable, and multiple clones were isolated and frozen.

Subsequently, the sensitivity of the ELISA was improved; the assay then showed that 14 of the original monoclonal antibodies cross-reacted with the staining fungus $O$. piceae. Five of the hybridomas having the strongest reactivity to $G$. roseum and showing varying degrees of cross-reactivity to $O$. piceae were chosen to produce ascites fluid. After a single-step purification by hydroxylapatite chromatography, the immunoglobulin classes and subclasses were determined using a commercially available kit. Of the five monoclonals processed in this way, two were identified as immunoglobulin $\mathbf{M}$ (IgM). These two monoclonals, 6A5 and $3 \mathrm{~F} 12$, were of high titre and showed excellent discrimination between the two fungi (Table 1). The other three monoclonal antibodies (IgG) were of lower titre and showed relatively high cross-reactivity with the staining fungus. For these assays, the plate wells were coated with an equal amount by dry weight of cell walls isolated from the two fungi. For wells containing $G$. roseum cell walls, the absorbance at $490 \mathrm{~nm}$ was greater than $1 \cdot 1$. For wells containing $O$. piceae cell walls, the absorbance with monoclonal antibodies $6 \mathrm{~A} 5$ and $3 \mathrm{~F} 12$ was less than $0 \cdot 1$, which we regard as background level. Similar discrimi- 


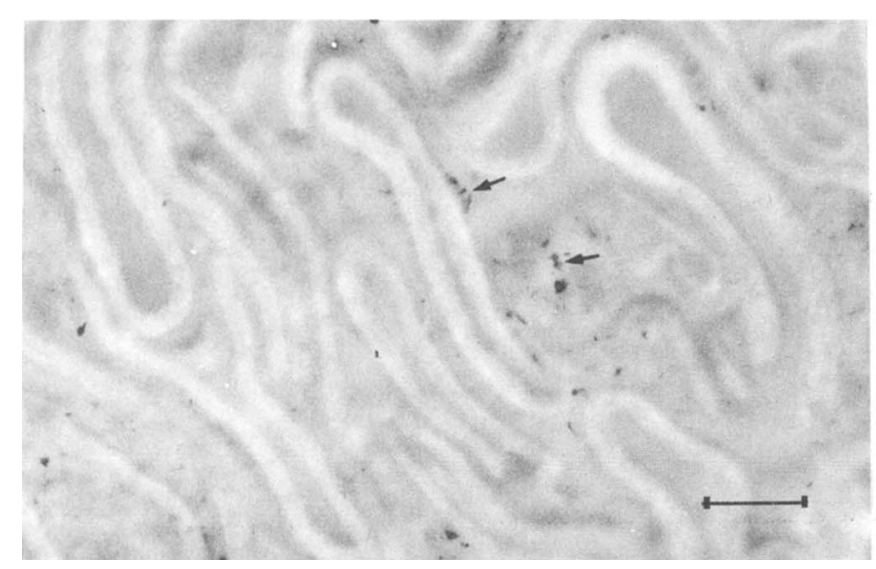

Fig. 1

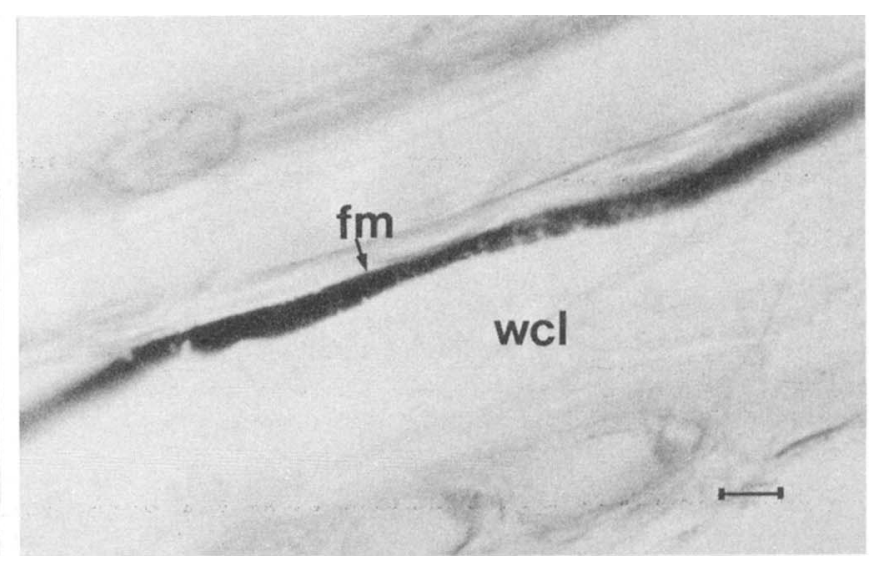

Fig 2.

Fig. 1. Electron micrograph of isolated cell walls of $G$. roseum. The isolated fraction contains primarily cell walls, $140 \mathrm{~nm}$ in width, consisting of inner and outer electron translucent layers and a darker staining middle layer. A small amount of electron dense contaminating material is also present (arrows). Bar, $0.5 \mu \mathrm{m}$.

Fig. 2. Light micrograph, immunogold silver staining with monoclonal antibody 6A5, of a semi-thin section of Pinus banksiana infected with $G$. roseum. The fungal mycelium is darkly stained and easily identified in the unstained wood cell lumen. fm, Fungal mycelium; wcl, wood cell lumen. Bar, $10 \mu \mathrm{m}$.

Table 1. Specificity and cross reactivity of the different purified monoclonal antibodies as determined by ELISA

\begin{tabular}{|c|c|c|c|c|c|}
\hline \multirow[b]{3}{*}{ Hybridoma } & \multirow[b]{3}{*}{ Dilution } & \multicolumn{4}{|c|}{ Reactivity in ELISA $\left(A_{490}\right)$} \\
\hline & & \multicolumn{2}{|c|}{ Ophiostoma piceae } & \multicolumn{2}{|c|}{ Gliocladium roseum } \\
\hline & & $\begin{array}{c}\text { Cell wall } \\
\left(100 \mu \mathrm{g} \mathrm{ml}^{-1}\right)\end{array}$ & $\begin{array}{c}\text { Whole cell } \\
\left(200 \mu \mathrm{g} \mathrm{ml}^{-1}\right)\end{array}$ & $\begin{array}{c}\text { Cell wall } \\
\left(100 \mu \mathrm{g} \mathrm{ml}^{-1}\right)\end{array}$ & $\begin{array}{l}\text { Whole cell } \\
\left(200 \mu \mathrm{gl}^{-1}\right)\end{array}$ \\
\hline $5 B 7$ & $1: 18$ & 0.14 & 1.35 & 2.53 & 1.78 \\
\hline 5D2 & $1: 18$ & $0 \cdot 19$ & 0.91 & $2 \cdot 40$ & 1.81 \\
\hline $6 \mathrm{~A} 5$ & $1: 100000$ & 0.01 & 0.03 & 1.74 & $2 \cdot 03$ \\
\hline 6E6 & $1: 500$ & 0.40 & 0.55 & 1.70 & 0.67 \\
\hline $3 F 12$ & $1: 100000$ & 0.01 & 0.03 & $1 \cdot 14$ & 1.50 \\
\hline
\end{tabular}

nation was seen using whole cell homogenates of the two fungi (Table 1).

\section{Specificity of the purified monoclonal antibodies}

To characterize further and assess the specificity of the two monoclonal antibodies against $G$. roseum, a number of sap-stain and potential biological control fungi grown in liquid culture were screened by the biotin-streptavidin ELISA. All screening was done with equal amounts by weight of whole cell homogenate sufficient to give an absorbance of 1.4 to 1.5 with monoclonal antibody 6A5 and $G$. roseum. Monoclonal antibody 6A5 recognized all five strains of $G$. roseum and $G$. catenulentum, and also detected the closely related Nectria cinnabarina to a lesser extent (Table 2), but did not cross-react with the other biological control fungi and gave background absor- bance values of less than $0 \cdot 1$ for 21 sap-stain fungi, including five strains of $O$. piceae and five other Ophiostoma (Table 3). In contrast, monoclonal antibody $3 \mathrm{~F} 12$ gave high absorbance readings of $40 \%$ to $200 \%$ of the $G$. roseum value for all but four of the biological control fungi (Table 2), and absorbance values of less than $0 \cdot 1$ for 19 of the 21 sap-stain fungi, but showed strong reactivity with two of the staining fungi (Cladosporium cladosporioides and Phoma sp.; Table 3).

The specificities of monoclonals $6 \mathrm{~A} 5$ and $3 \mathrm{~F} 12$ were also assessed for several fungi growing on wood by IGSS and light microscopy (Fig. 2). Monoclonal 6A5 was positive for $G$. roseum and $G$. catenulentum and also reacted with $N$. cinnabarina, but did not recognize the other biological control fungi (Table 2). Monoclonal 3 F12 was strongly positive with 10 of the 12 biological control fungi tested (Table 2). No detection by IGSS was 
Table 2. Reactivity of monoclonal antibodies $6 A 5$ and $3 F 12$ with different biological control fungi grown in liquid media or in wood

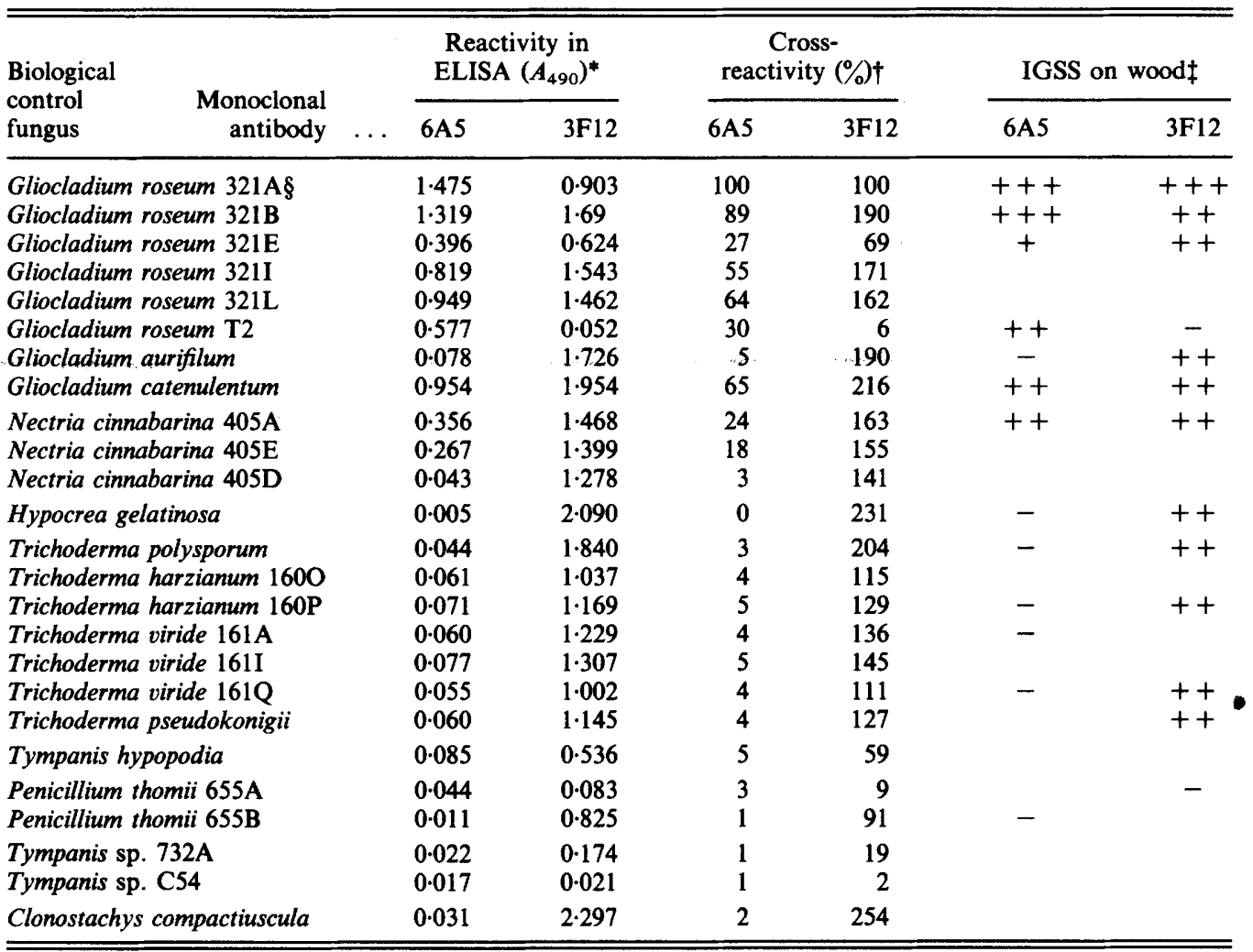

* ELISA using equal amounts by weight of whole cell homogenate of fungi grown in liquid culture.

+ Reactivity of biological control fungi as a percentage of that of $G$. roseum $231 \mathrm{~A}$.

$\ddagger$ Immunogold-silver staining observations ( + , extent of labelling; - , background levels of labelling).

$\S G$. roseum strain used to raise monoclonal antibody 6 A5.

seen for either $6 \mathrm{~A} 5$ or $3 \mathrm{~F} 12$ when tested on 12 sapstaining fungi (Table 3).

\section{Characterization of the antigens}

Analysis of $6 \mathrm{~A} 5$ and $3 \mathrm{~F} 12$ immunoreactivity was also done by Western blotting of $G$. roseum and $O$. piceae cell wall protein extracts (Fig. 3). Both monoclonal antibodies demonstrated strong staining of the $G$. roseum sample, with 6A5 (lane 2) showing a high molecular mass smear, and 3F12 (lane 3) detecting a single band at about $110 \mathrm{kDa}$ and a slight high molecular mass smear. No signal was detected in the $O$. piceae sample with either monoclonal antibody (lanes 5, 6).

To determine if the epitopes recognized by these monoclonals included carbohydrate, samples were treated with sodium metaperiodate. Such treatment of $G$. roseum cell walls rapidly reduced, as assayed by ELISA, the ability of the cell walls to bind monoclonals 6A5 and $3 \mathrm{~F} 12$. After $1 \mathrm{~h}$ of treatment the binding was reduced by $90 \%$ and after $4 \mathrm{~h}$ the binding was negligible.

\section{Electron microscopy and immunogold labelling of $G$. roseum and $O$. piceae}

Following treatment of intact cells with monoclonals 6A5 and 3F12 and subsequent immunogold treatment, the cell walls were seen to be labelled (Fig. 4). Luck et al. (1990) described the cell wall of $G$. roseum as consisting of inner and outer translucent layers and a darker staining middle layer. This wall (140 nm thick) is surrounded by a loosely arranged fibrillar sheath of variable thickness and electron opacity. Monoclonal 6A5 primarily labelled the outermost layer of the wall (Fig. $4 a$ ), whereas $3 \mathrm{~F} 12$ primarily labelled the innermost layer of the wall (Fig. $4 b$ ). Neither of the antibodies labelled the fibrillar sheath. These patterns of labelling were seen for approximately $70 \%$ of the total cell population. However, cells judged to be young, by the presence of few cytoplasmic vacuoles and darkly staining protoplasm, were devoid of label with either of the antibodies (not shown).

Both 6A5 and $3 \mathrm{~F} 12$ also recognized antigens on 
Table 3. Reactivity of monoclonal antibodies $6 A 5$ and $3 F 12$ with different staining fungi grown in liquid media or in wood

\begin{tabular}{|c|c|c|c|c|c|c|c|}
\hline \multirow{2}{*}{$\begin{array}{l}\text { Staining } \\
\text { fungus }\end{array}$} & & \multicolumn{2}{|c|}{$\begin{array}{l}\text { Reactivity in } \\
\text { ELISA }\left(A_{490}\right)^{*}\end{array}$} & \multicolumn{2}{|c|}{$\begin{array}{l}\text { Cross- } \\
\text { reactivity }(\%) \dagger\end{array}$} & \multicolumn{2}{|c|}{ IGSS on wood $\ddagger$} \\
\hline & $\cdots$ & 6A5 & $3 \mathrm{~F} 12$ & $6 \mathrm{~A} 5$ & $3 \mathrm{~F} 12$ & $6 \mathrm{~A} 5$ & $3 F 12$ \\
\hline Gliocladium roseum $321 \mathrm{~A} \S$ & & 1.475 & 0.903 & 100 & 100 & +++ & +++ \\
\hline Ophiostoma piceae $387 \mathrm{E}$ & & 0.010 & 0.007 & 1 & 1 & - & - \\
\hline Ophiostoma piceae $387 \mathrm{H}$ & & 0.055 & 0.013 & 2 & 1 & & \\
\hline Ophiostoma piceae $387 \mathrm{I}$ & & 0.005 & 0.020 & 0 & 2 & - & - \\
\hline Ophiostoma piceae $387 \mathrm{~J}$ & & 0.010 & 0.008 & 1 & 1 & - & - \\
\hline Ophiostoma piceae $387 \mathrm{~N}$ & & 0.012 & 0.008 & 1 & 1 & & \\
\hline Ophiostoma sp. C28 & & 0.052 & 0.049 & 3 & 5 & - & - \\
\hline Ophiostoma piliferum & & 0.008 & 0.011 & 0 & 1 & - & - \\
\hline Ophiostoma ulmi & & 0.010 & 0.011 & 1 & 1 & - & - \\
\hline Ophiostoma populinum & & 0.008 & 0.001 & 0 & 0 & & \\
\hline Ophiostoma ainoae & & 0.013 & 0.004 & 1 & 0 & & \\
\hline Rhinocladiella atrovirens & & 0.011 & 0.066 & 1 & 7 & - & - \\
\hline Ceratocystis adiposa & & $0 \cdot 015$ & 0.033 & 1 & 4 & - & - \\
\hline Cephaloascus fragrans & & 0.039 & 0.031 & 3 & 4 & - & - \\
\hline \multicolumn{8}{|l|}{ Aureobasidium pullulans } \\
\hline var. melanogenus & & 0.030 & 0.031 & 2 & 4 & - & - \\
\hline Phialophora botulispora & & 0.029 & 0.013 & 2 & 2 & - & - \\
\hline Alternaria alternata & & 0.013 & 0.011 & 2 & 1 & - & - \\
\hline Leptondontidium elatius & & 0.073 & 0.070 & 5 & 8 & & \\
\hline Cladosporium cladosporioides & & 0.097 & 0.982 & 6 & 109 & & \\
\hline Phoma sp. & & 0.082 & 0.629 & 5 & 70 & & \\
\hline Black yeast & & 0.026 & 0.032 & 2 & 3 & & \\
\hline Leptographium sp. & & 0.056 & 0.026 & 4 & 3 & & \\
\hline
\end{tabular}

* ELISA using equal amounts by weight of whole cell homogenate of fungi grown in liquid culture.

$\dagger$ Reactivity of staining fungi as a percentage of that of $G$. roseum $321 \mathrm{~A}$.

$\ddagger$ Immunogold-silver staining observations ( + , extent of labelling; - , background levels of labelling).

$\S$ G roseum strain used to raise monoclonal antibody $3 \mathrm{~F} 12$.

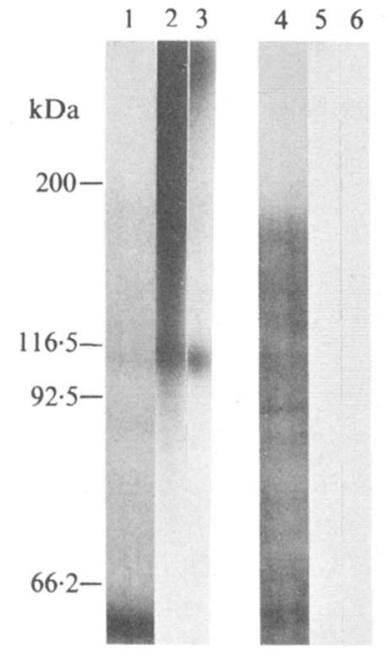

Fig. 3. Western blotting with monoclonals 6A5 and 3F12 against SDS extracts of cell walls isolated from $G$. roseum (lanes 1-3) and $O$. piceae (lanes 4-6). India ink staining for total protein is seen in lanes 1 and 4, $6 \mathrm{~A} 5$ staining in lanes 2 and 5 , and $3 \mathrm{~F} 12$ staining in lanes 3 and 6. isolated cell walls of $G$. roseum (Fig. $4 c, d$ ). For both antibodies the label was non-uniform, appearing as groups of gold particles scattered at intervals on the outer surfaces, and in some cases also the inside, of the walls. Application of the two monoclonals to sections of $O$. piceae cells (Fig. $4 e$ ) or to sections of isolated $O$. piceae cell walls (not shown) gave only a few scattered gold particles that were attributed to background. Control samples of $G$. roseum, in which PBS was substituted for the primary antibody (either $6 \mathrm{~A} 5$ or $3 \mathrm{~F} 12$ ), also showed only background levels of gold label (not shown).

\section{Discussion}

The two monoclonal antibodies described in this paper specifically recognized separate layers of the cell wall of whole cells of $G$. roseum by immunogold electron microscopy and did not label the walls of $O$. piceae. Both monoclonals also recognized components of isolated cell 

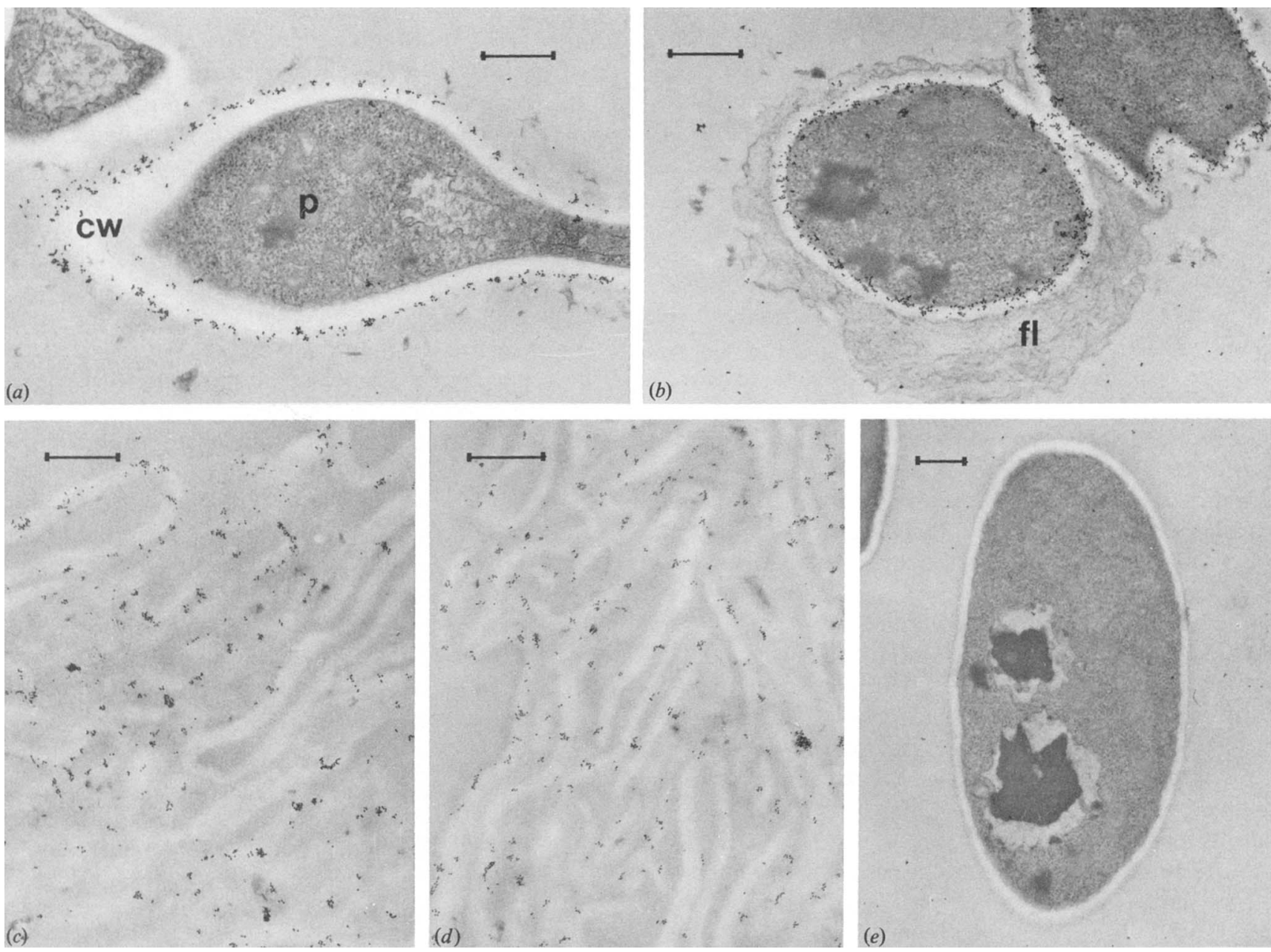

Fig. 4. Electron micrographs of immunogold labelled fungal cells and isolated cell walls. Bars, $0.5 \mu \mathrm{m}$. (a) Portion of a $G$. roseum hypha labelled with monoclonal 6A5. The label is localized in the outer layer of the cell wall (cw) and only a low background level of label is detected over the protoplasm (p). (b) G. roseum cells labelled with monoclonal $3 \mathrm{~F} 12$ showing localization of label in the inner layer of the cell wall. The fibrillar layer (f) that is external to the cell wall is not labelled. $(c, d)$. Isolated $G$. roseum cell walls labelled with $6 \mathrm{~A} 5$ and $3 \mathrm{~F} 12$, respectively. For both antibodies the label is non-uniformly distributed over the walls. $(e) O$. piceae cell labelled with antibody 6A5, showing only low levels of background labelling.

walls of $G$. roseum by immunogold electron microscopy, but the distribution of label was no longer uniform along the walls. This change in distribution (or detection) of the epitopes may be due to redistribution, denaturation or extraction of wall components during cell wall isolation. It is clear that the fibrillar sheath seen on the outside of the wall of intact mycelia is removed during the isolation procedure.

Immunoblotting of SDS extracts from isolated fungal cell walls also showed that both monoclonals discriminated between the two fungal species. Monoclonal 6A5 recognized many components on the blot of $G$. roseum cell wall extract, including the $110 \mathrm{kDa}$ band recognized by $3 F 12$, and gave a smear of reaction to the top of the blot. 3 F 12 showed a more restricted detection, but also gave a smear in the region near the top of the blot. Several observations indicate that both monoclonals are probably directed against carbohydrate epitopes of polysaccharide complexes and/or glycoproteins. (1) The SDS gel of the cell wall extracts showed numerous bands, many of which were obscured by a diffuse smear of staining. Such a smear could be due to polysaccharide complexes, carbohydrate-rich glycoproteins or lipids (Reiss et al., 1986; Kamel et al., 1989; Hames, 1990). Carbohydrate-rich glycoproteins are known to behave anomalously in SDS-PAGE, migrating with reduced mobilities (Reiss et al., 1986; Hames 1990). They also stain poorly using general protein stains such as Coomassie blue (Haselbeck \& Hosel, 1990), which might explain the absence of staining in the high molecular 
mass region on our gel. (2) A smear similar to that detected by immunoblotting with monoclonal 6A5 was also seen when the blot was stained for glycoproteins using the Boehringer-Mannheim glycan detection kit (unpublished observations). (3) Periodate treatment of $G$. roseum cell walls, which modifies carbohydrates by oxidation of sugar residues and has been shown to alter binding of antibodies to glycoproteins (Hearn et al., 1990), drastically reduced the binding of the monoclonals to the isolated cell walls. (4) In addition, as noted above, antibodies which recognize carbohydrate moieties of complex polysaccharides and glycoproteins are the most common result of immunizations with fungal cell walls.

The monoclonal antibodies 6A5 and 3F12 not only discriminated between $O$. piceae and $G$. roseum, but also showed restricted recognition of other fungi tested. $3 F 12$ recognized only two of the sap-stain fungi tested, but reacted with most of the other potential biological control fungi. This monoclonal antibody may, therefore, be of value for monitoring several different biological control fungi in controlled infection experiments. 6A5 did not recognize any of the sap-stain fungi tested and reacted with only a few of the biological control fungi. Consequently, 6A5 could be used to monitor the presence and the growth in wood of $G$. roseum and other Gliocladium species, or the closely related genus Nectria, in the presence of a variety of staining or other biological control fungi.

As mentioned above, the second goal of this study was to produce monoclonals that would be of value for the detection of $G$. roseum growing on wood. It was quite possible that the same fungus growing in wood as opposed to growing in liquid culture might show differences in cell wall structure and/or composition that would reduce or abolish its detection by a particular antibody. Differences in expression of fungal cell surface/wall antigens have been shown to occur depending on: (a) whether growth was in vitro or in vivo (Brawner \& Cutler, 1987); (b) culture conditions such as the type and concentration of nitrogen source used, the amount of the inoculum, and the age of the mycelium (Burrell et al., 1966); and (c) the phase of fungal growth (Smail \& Jones, 1984; Sundstrom et al., 1987; Leusch, 1989; Casanova et $a l ., 1989)$. In our work, we also noted a difference in the detection of the antigens recognized by monoclonals $6 \mathrm{~A} 5$ and $3 \mathrm{~F} 12$ on mycelia grown in liquid culture. The lack of detection of some mycelia by the immunogold electron microscopy method appeared to be related to the age of the cells, but we have not yet directly monitored the appearance of these antigens as a function of culture age.

We have shown that the cross-reactivities of monoclonals $6 \mathrm{~A} 5$ and $3 \mathrm{~F} 12$ as measured by the IGSS light microscopy method with a selection of 12 sap-stain and 12 biological control fungi grown on wood matched the cross-reactivities determined by ELISA for the same fungi grown in liquid culture. Therefore, both of these antibodies will be of use for our ongoing studies of fungal growth on wood substrates. For monitoring such growth, we have concentrated on the application of microscopic immunodetection methods. For detection and localization at the electron microscope level we have found that immunogold labelling of thin sections of fixed and embedded samples works equally well for staining and control fungi growing in liquid culture and in wood (Fig. $4 a, b$; Luck et al., 1990; and unpublished observations). For detection by light microscopy we have tested a variety of immunofluorescence and colorimetric methods and have found that the IGSS method is by far the best for the localization of staining fungi and biological control fungi in wood (Fig. 2, and Breuil et al., 1990). This technique is simple and rapid and, with appropriate specific antibodies such as those described in this study, together with other monoclonal antibodies specific to species of Ophiostoma (Dewey et al., 1986; Benhamou et al., 1985) can be used for the detection of specific fungi in wood as well as for basic studies on the colonization of wood by fungi and of the interactions of different fungi growing together on wood.

This study was supported by Forestry Canada and by a Cooperative Research and Development Grant from the Natural Sciences and Engineering Research Council of Canada. The authors express their thanks to Ms B. Valentine for her expert technical assistance.

\section{References}

Banowetz, G. M., Trione, E. J. \& Krygier, B. B. (1984). Immunological comparisons of teliospores of two wheat bunt fungi, Tilletia species, using monoclonal antibodies and antisera. Mycologia 76, 51-62.

Benhamou, N., Ouellette, G. B., Lafontaine, J. G. \& Joly, J. R. (1985). Use of monoclonal antibodies to detect a phytotoxic glycopeptide produced by Ophiostoma ulmi, the Dutch elm disease pathogen. Canadian Journal of Botany 63, 1177-1184.

Brawner, P. L. \& CutLer, J. E. (1987). Cell surface and intracellular expression of two Candida albicans antigens during in vitro and in vivo growth. Microbiological Pathology 2, 249-257.

Breuil, C., Yamada, J., Seifert, K. A. \& Saddler, J. N. (1988a). An enzyme-linked immunosorbent assay for detecting staining fungi in unseasoned wood. Journal of the Institute of Wood Sciences 11, 132134.

Breuil, C., Seifert, K. A., Yamada, J., Rossignol, L. \& Saddler, J. N. (1988b). Quantitative estimation of fungal colonization of wood using an enzyme-linked immunosorbent assay. Canadian Journal of Forest Research 18, 374-377.

Breuil, C., LuCK, B. T., Rossignol, L., Little, J. \& Brown, D. L. (1990). The visualization of fungal infection wood using immunogold silver staining and light microscopy. Journal of the Institute of Wood Sciences 12, 77-81.

Burrell, R. G., Clayton, C. W., Gallegly, M. E. \& Lilly, V. G. (1966). Factors affecting the antigenicity of the mycelium of three species of Phytophthora. Phytopathology 56, 422-426.

CAMPBeLl, A. M. (1984). Laboratory techniques: monoclonal antibody technology. In Biochemistry and Molecular Biology 13. Edited by R. H. Burdon \& P. H. Van Knippenberg. Amsterdam: Elsevier Scientific. 
Casanova, M., Gil, M. L., Gardenoso, L., Martinez, J. P. \& SENTANDREU, R. (1989). Identification of wall-specific antigens synthesized during germ tube formation by Candida albicans. Infection and Immunity 57, 262-271.

Chaly, N., Bladon, T., Setterfield, G., Little, J. E., Kaplan, J. G. \& Brown, D. L. (1984). Changes in distribution of nuclear matrix antigens during the mitotic cell cycle. Journal of Cell Biology 99, 661671 .

Dewey, F. M., MacDonald, M. M. \& Phillips, S. I. (1989a). Development of monoclonal-antibody ELISA, -dot-blot and -dipstick immunoassays for Humicola lanuginosa in rice. Journal of General Microbiology 135, 361-374.

Dewey, F. M., Munday, C. J. \& Brasier, C. M. (1989b). Monoclonal antibodies to specific components of the Dutch elm disease pathogen Ophiostoma ulmi. Plant Pathology 38, 9-20.

Green, F., Clausen, C. A., Larsen, M. J. \& Highley. (1991). Immunoscanning electron microscopic localization of extracellular polysaccharidases within the fibrillar sheath of the brown-rot fungus Postia placenta. International Research Group on Wood Protection 1497, 1-11

HAMES, B. D. (1990). One-dimensional polyacrylamide gel electrophoresis. In Gel Electrophoresis of Proteins, 2nd edn, pp. 1-147. Edited by B. D. Hames \& D. Rickwood. Oxford: IRL Press.

HASELBECK, A. \& HoSEL, W. (1990). Description and application of an immunological detection system for analyzing glycoproteins on blots. Glycoconjugate 7, 63-74.

hearn, V. M., Wilson, E. V., Latgé, J. P. \& Mackenzie, D. W. R. (1990). Immunochemical studies of Aspergillus fumigatus mycelial antigens by polyacrylamide gel electrophoresis and Western blotting techniques. Journal of General Microbiology 136, 1525-1535.

Holgate, C. S., Jackson, P., Cowen, P. N. \& Bird, C. C. (1983). Immunogold-silver staining: new method of immunostaining with enhanced sensitivity. Journal of Histochemistry and Cytochemistry 31, 938-944.

Kamel, S. M., Wheat, L. J., Garten, M. L., Bartlett, M. S., Tansey, M. R. \& TEWARI, R. P. (1989). Production and characterization of murine monoclonal antibodies to Histoplasma capsulatum yeast cell antigens. Infection and Immunity 57, 896-901.

KENNETT, R. H. (1984). Fusion by centrifugation of cells suspended in polyethylene glycol. In Monoclonal Antibodies, pp. 365-367. Edited by R. H. Kennett, T. J. McKearn \& K. B. Bechtol. New York: Plenum Press.

LAEMmLI, U. K. (1970). Cleavage of structural proteins during the assembly of the head of bacteriophage T4. Nature, London 227, 680 685
LeUSCH, H.-G. (1989). Detection and characterization of two antigens specific for cell walls of Candida albicans mycelial growth phase. Current Microbiology 19, 193-198.

LuCK, B. T., BreuIL, C. \& Brown, D. L. (1990). Immunological discrimination between a sap-staining and a biological control fungus. Canadian Journal of Botany 68, 1578-1588.

MCHALE, A. P. (1987). Production and characterization of monoclonal antibodies to the cellulases produced by Talaromyces emersonii CBS 814.70. Biochimica et Biophysica Acta 924, 147-153.

Mitchell, L. A. (1986). Derivation of Sirococcus strobilinus specific monoclonal antibodies. Canadian Journal of Forest Research 16, 939944.

Nieves, R. A., Ellis, R. P., Todd, R. J., Johnson, T. J. A., GrohmanN, K. \& Himmel, M. E. (1991). Visualization of Trichoderma reesei cellobiohydrolase I and endoglucanase I on aspen cellulose using monoclonal antibody-colloidal gold conjugates. Applied and Environmental Microbiology 57, 3163-3170.

Ouellette, G. B. \& Benhamou, N. (1987). Use of monoclonal antibodies to detect molecules of fungal plant pathogens. Canadian Journal of Plant Pathology 9, 167-176.

Reiss, E., Knowles, J. B., Bragg, S. L. \& Kaufman. (1986). Monoclonal antibodies against the $\mathbf{M}$-protein and carbohydrate antigens of histoplasmin characterized by the enzyme-linked immunoelectrotransfer blot method. Infection and Immunity 53, 540546.

Seifert, K. A., Breull, C., Rossignol, L., Best, M. \& SAddler, J. N. (1988). Screening for microorganisms with the potential for biological control of sap-stain in unseasoned lumber. Material und Organisms 23, 81-95.

SMaIL, E. H. \& Jones, J. M. (1984). Demonstration and solubilization of antigens expressed primarily on the surfaces of Candida albicans germ tubes. Infection and Immunity 45, 74-81.

Smith, P. K., Krohn, R. I., Hermanson, G. T., Mallia, A. K., Gartner, F. H., Provenzano, M. D., Fujimoto, E. K., Goeke, N. M., Olson, B. J. \& KLENK, D. C. (1985). Measurement of protein using bicinchoninic acid. Analytical Biochemistry 150, 76-85.

Stanker, L. H., VanderlaAn, M. \& Juarez-Salinas, H. (1985). Onestep purification of mouse monoclonal antibodies from ascites fluid by hydroxylapatite chromatography. Journal of Immunological Methods 76, 157-169.

Sundstrom, P. M., Nichols, E. J. \& KenNY, G. E. (1987). Antigenic differences between mannoproteins of germ tubes and blastospores of Candida albicans. Infection and Immunity 55, 616-620.

Voller, A., Bidwell, D. E. \& Bartlett, A. (1979). The enzymelinked immunosorbent assay (ELISA). Dynatech Laboratories Inc., Alexandria, VA. 